\title{
人工放射性同位元素 $\mathrm{P}^{32}$ を用い:た分裂病者の
}

\section{血 液 燐劃分に就て}

岡山大学医学部精神病举教室（主任 藤源高司救授）

$\begin{array}{llll}\text { 藤 } & \text { 原 } & \text { 高 } & \text { 司 } \\ \text { 難 } & \text { 波 } & \text { 益 } & \text { 之 } \\ \text { 大 } & \text { 月 } & \text { 三 } & \text { 郎 }\end{array}$

[昭和 28 年 12 月 5 日受稿]

\section{I 緒 言}

著者等の一人藤原”は既飞分裂病者に就て 血液の燐劃分を検し，慢性型飞於てピ口燐酸 が多く，急性型に於て少いことを認めた。 そ れはいわぼ静的状態の観察であつたが放射性 P32 用いれば動的な状態が知られる筈であ。 る.この目的でなされたのが本実験であ る.

\section{I 英㯺材料及び賽驗方法}

患者の年令は 20 才より 40 才迄の男女を大 体同数採り，発熟その他の身体症状を有しな い者を邀び，対照としては 3 人の神終所腎者 を选んだ.
凡ての実験飞於て, 早朝空腹洔飞 $\mathrm{NaHP}^{32} \mathrm{O}_{4}$ の蒸溜水稀譒液を $0,03 \mathrm{mC}$ の割合で时静脉飞 注射し，朝食を与兄ず安静にして 2 時間後に 反対側时静脉から採血し, 直ちに氷冷しなが ら $7 \%$ 三塩化醋酸 5 c.c. を加兄 $0^{\circ} \mathrm{C} 10$ 分間放 置後滤過し, 滤液飞就いて Lohmann 2) の記 載飞従い血中酸可溶性燐にういて検討した. 各燐劃分の計数値より Bomskov ${ }^{3)}$ に従つて無 機燐酸，ピロ燐酸，へキソーゼェステル燐酸 を算出した。

\section{1 赛 驗 成 綪}

藤源の以前の記述に従ひ，急性型と慢性型 に分けて垁験絬果を表飞示すと第I表の如く である.

第 I 表

〔急性型〕 $\mathrm{P}^{3 n}$ 静注後 2 時間 の計数倠

\begin{tabular}{|c|c|c|c|c|c|c|c|c|c|c|}
\hline & 氏 & 名 & 年令 & 性别 & $\mid \begin{array}{l}\text { 癸病 } \\
\text { 経浧 }\end{array}$ & $\begin{array}{l}\text { 来の } \\
\text { 日数 }\end{array}$ & 吉なる 症 状 & 無誡螣酸 & ピ口燐饿 & $\left\{\begin{array}{l}\text { ニキンー七 } \\
\text { エステル性政 }\end{array}\right.$ \\
\hline \multirow{2}{*}{ 好 } & 岸 & 上 & 22 & $\hat{\delta}$ & 2 & 月 & 內的興䏸，体感如觉 & 124 & 98 & 4 \\
\hline & 大 & A & 17 & 字 & 1 & 月 & 㕵 洣，絾 默，拒 食 & 365 & 198 & 34 \\
\hline \% & 高 & 杉 & 30 & 후 & 4 & 日 & 病感 有，感 情 易 变 & 185 & 59 & 0 \\
\hline \multirow{3}{*}{ 檼 } & 松 & 石 & 17 & $\boldsymbol{\delta}$ & 1 & 月 & 乱 & 120 & 73 & $\mathbf{0}$ \\
\hline & 能 & 口 & 23 & t & 6 & 月 & 離人症，蹯膈体踰，抑 5つ & 95 & 88 & 11 \\
\hline & 佐 & 藤千 & 16 & क & 1 & 月 & 裂，興 & 111 & 77 & 80 \\
\hline \multirow{4}{*}{ 化 } & 安 & 井 & 20 & 字 & 2 & 月 & 奵 党，务的，興 控 & 111 & 64 & 17 \\
\hline & 谷 & 口 & 22 & 午 & 2 & 月 & 緘默, 注視及び网係念虑 & 215 & 37 & 53 \\
\hline & 森 & 口 & 23 & + & 5 & 月 & 婑张症 & 97 & 29 & 0 \\
\hline & 落 & 合 & 26 & 우 & 4 & 日 & 失見当䤘，皆 㴹 状 & 148 & 100 & 7 \\
\hline
\end{tabular}


〔慢性型〕 $\mathrm{P}^{32}$ 静注後 2 時間の計数值

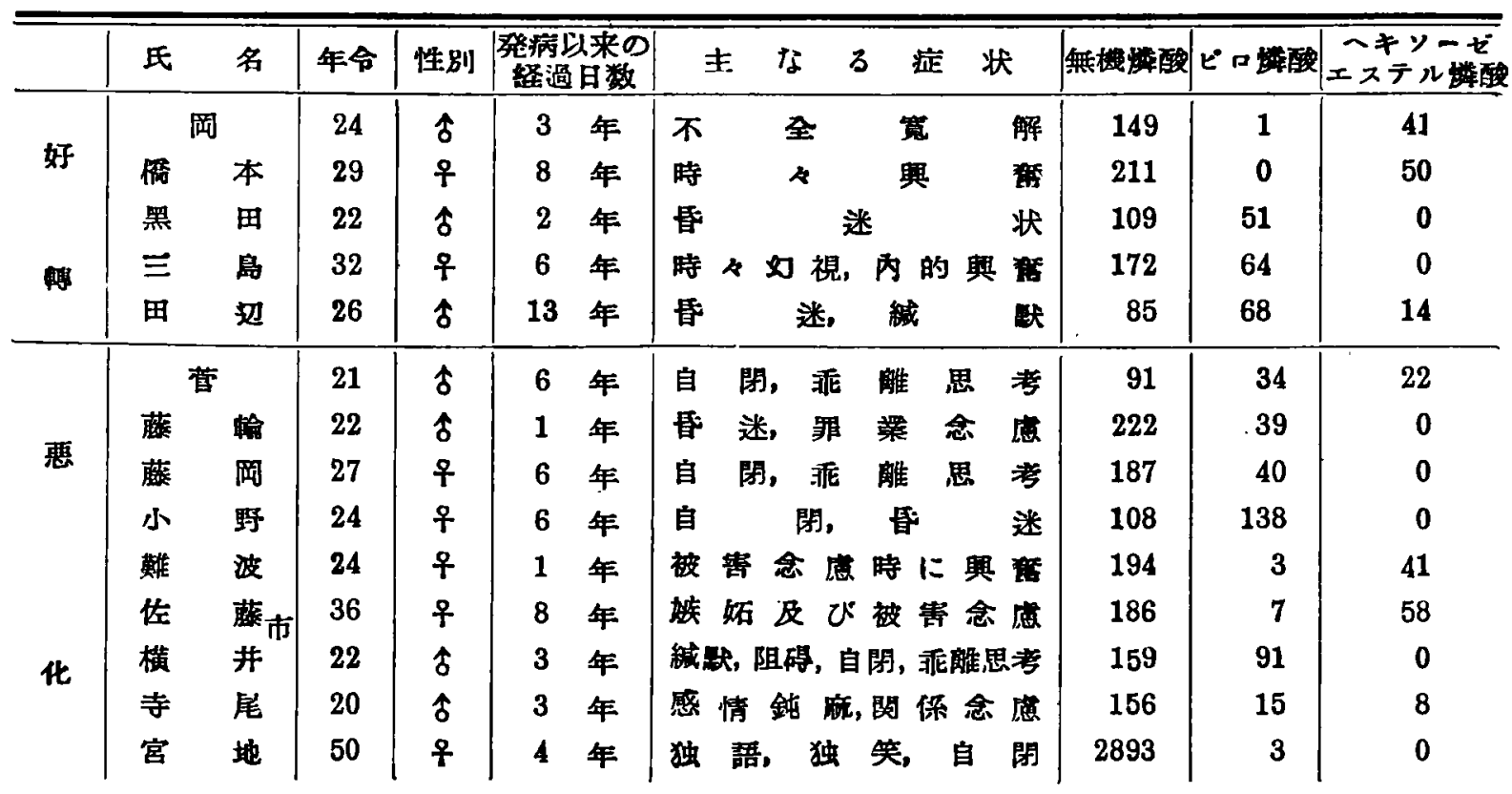

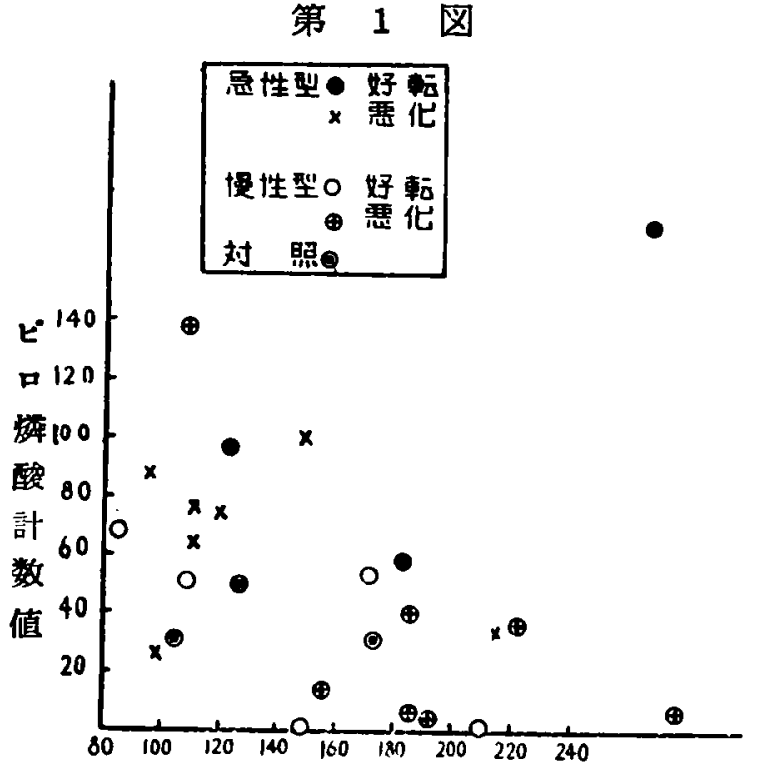

無機燐酸竍数值

血中無機燐酸とピ口權酸の劃分の計数值の 相互関係を見ると第 1 図の如く，急性型では 症状の好転, 悪化共飞左上方飞一群を形成 し，之に対して慢性型は右下方に位置して散 在している，唯，慢性型の中 2例だけが急性 型群に混入している。これとは 1 例の好枟例 と 1 例の悪化例が含まれているが前者は検查 1 週間前興窞錯乱状態飞陌いつていて漸く 2 日前から安静を取杘したものの，尚多少の舆 窗を残している状態であり，後者は錯乱状態 を持続していたものでその症状からしても何 れも急性要化例と称してもよいるのであつ
た. 又急性型の中 3 例が慢性型群飞混入して いるがその意味については今の所明らかでな い.

次にビ口橉酸の計数值と臨牀症状との関係 をより明瞭に表わすために第 2 図をあげた。

第 2 図

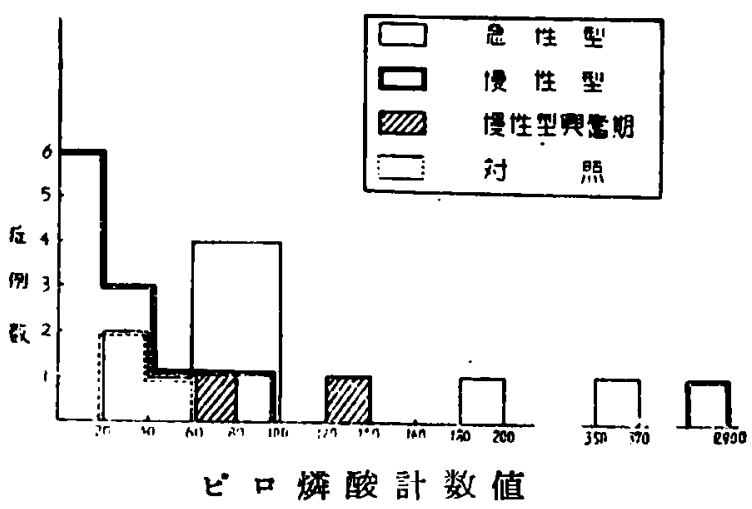

之に依つて見ると急性型及び慢性型の中で も前記 2 例のよ5な興蟹期にあるるのは，凡 て 60 以上飞位置し，以下対照例を中間飞は さんで，急性型ではピロ燐酸の turnover rate が正常より高く，慢性型では低下しているこ とが羿められる。

第【表は無機燐酸とビ口燐酸との量的関係 を時間を追つて調へたるのであり，第 3 図る 同棣な目的でより短㸝間の間隔で観祭したも のだが，これらの結果から，血中に注射され た $\mathrm{P}^{32}$ は既に 10 分後にはビ口燐酸劃分に入 
つていて，2 時閒でほぼ最高に達することが 知れる.

\begin{tabular}{|c|c|c|c|c|c|}
\hline & 氏名 & \begin{tabular}{|l} 
注射後 \\
堔血時間
\end{tabular} & 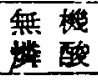 & 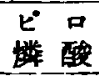 & $\begin{array}{l}\text { ニキソーゼ } \\
\text { エステル嫾酸 }\end{array}$ \\
\hline \multirow{4}{*}{$\begin{array}{l}\text { 急 } \\
\text { 性 } \\
\text { 型 }\end{array}$} & \multirow[t]{2}{*}{ 岸上 } & 2時間 & 124 & 90 & 4 \\
\hline & & 24 時間 & 51 & 0 & 0 \\
\hline & \multirow[t]{2}{*}{ 森口 } & 2時間 & 77 & 28 & 0 \\
\hline & & 24 時間 & 48 & 0 & 13. \\
\hline \multirow{2}{*}{$\begin{array}{l}\text { 慢 } \\
\text { 性 } \\
\text { 型 }\end{array}$} & \multirow[t]{2}{*}{ 宮地 } & 2 時間 & 2893 & 3 & 0 \\
\hline & & 24時間 & 79 & 13 & 13 \\
\hline
\end{tabular}

第 3 図

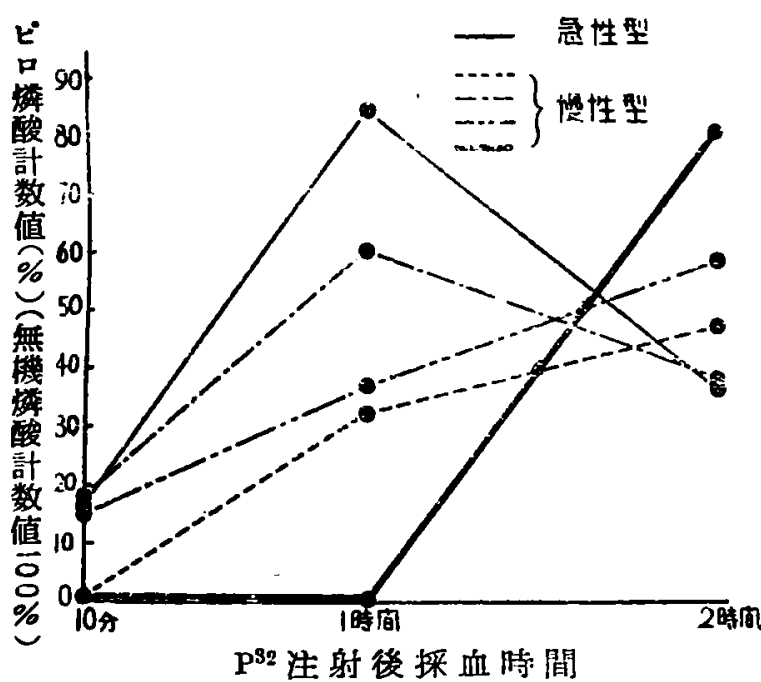

Örström9) は私達と同栐の奏験の結果， へ キソーゼェステル燐酸が感情易变性並飞感情 鈍麻性分裂病飞於て前者飞大で後者に小なる ことを認めているが，私達の契験でもこのこ と住確認された。（第4図）

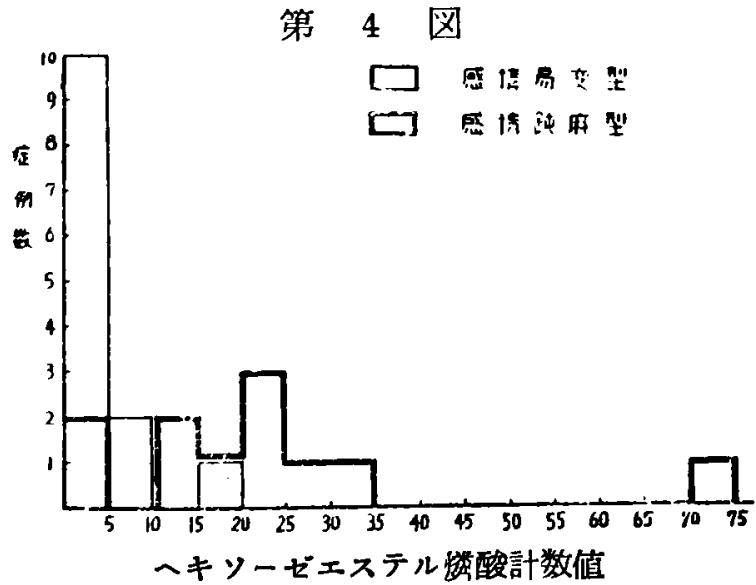

文

1) 林 道偷; 精神神経学䧱誌, $51,193,1950$.

2) Lohmann ; Biochem. Ztschr., 202, 466, 1928.

3) Bomskov ; Z. Physiol. Chem., 210, 67, 1932.

\section{IV考察及び結論}

以上の実験で先ず目につくのは，ビロ橉酸 劃分に於ける所見である。即ち急性型もしく は慢性型で尚興窑状態にあるるのは，無機燐 酸よりピロ榤酸への turnover rate が高い. 之に対して慢性型では対照以下であり，耐者 は対照例を中間に招いて互に相反した值を示 す.

この事実はつまり急性型ではピロ燐酸の消 費が対照に比して多く慢性型は少ないことを 示するのであり，藤原が以前認めた，慢性 型飞於て多く，急性型飞於て少いと云う事実 を装其きするものである。

更に又 turnover rate を時間的に観察して 見ると，第【表及び第 3 図の示すよ5に急性 型に較べて明らかな差違があり，慢性型では 24 時間後も無機橉の多量が血中に存在して いたような例もあり，その緩慢な turnover rate の状態が窺われる

ヘキソーゼェステル橉酸值に就いては Örström す私達と同様な所見を記載しているこ とは前に述べた通りである。

以上を要約すると次のよ 5 K云えるである 3.

1）分烈病者の血中に注射した $\mathrm{P}^{32}$ は急速 にビロ燐酸に移行し，速いるので一時間，遅 いものでる 2 時間前後で最高飞達し，24 㭙間 を経ると $\mathrm{P}^{32}$ は大部分血中酸可溶性副分より 去る。

2） 2 時間後採血では急性型はビロ燐酸の turnover rate $か ゙$ 高く. 慢性型の興凅期も同様 な倬を示す。慢性型はさに反して対照例より む低下している，対照例は両者の中間に位置 する.

3）感情易変型はへキソーゼェステル劃分 の turnover rate が高く, 鈍麻型は低いこと を示している。

\section{献}

4) Örström ; acta psychiat. et neurol. Supplementum: 47, 118, 1947. 